\title{
Screening of Diploid cotton genotypes against Fusarium oxysporum f.sp. vasinfectum
}

D.H. SARNOBAT* AND K.B. PAWAR

Plant Pathology Section, College of Agriculture, PUNE (M.S.) INDIA

\begin{tabular}{lll} 
ARITCLE INFO \\
\hline Received & $:$ & 29.07 .2014 \\
Revised & $:$ & 09.01 .2015 \\
Accepted & $:$ & 23.01 .2015 \\
\hline
\end{tabular}

\section{KEY WORDS :}

Diploid cotton, Fusarium wilt, Screening, F. oxysporum f.sp. vasinfectum

*Corresponding author: Email: dhanu.dhemre@ rediffmail.com

\begin{abstract}
Cotton wilt incited by Fusarium oxysporum f.sp. vasinfectum is one of the most serious disease inflicting unaccountable quantitative as well as qualitative losses. A total of 310 diploid cotton genotypes were evaluated under glasshouse and field conditions. Results showed that all the genotypes screened, exhibited varied degree of reactions against $F$. oxysporum f.sp. vasinfectum. Among 310 Diploid cotton genotypes, only six showed resistant reaction and twenty genotypes showed moderately resistance reaction in seedling resistance reaction. Out of these 26 cotton genotypes, 8 genotypes showed resistant reaction in Adult Plant Resistant Test.

How to view point the article : Sarnobat, D.H. and Pawar, K.B. (2015). Screening of Diploid cotton genotypes against Fusarium oxysporum f.sp. Vasinfectum. Internat. J. Plant Protec., 8(1) : 26-29.
\end{abstract}

